\title{
THE WRITER'S VOICE: EXPLOITING ORAL DISCOURSE STRATEGIES IN THE TEACHING OF SECOND LANGUAGE LITERACY
}

\section{J. T. von Gruenewaldt}

\section{INTRODUCTION*}

The aim in this paper is firstly to assess the problematic relationship between $L 1$ and L2 literacy in South Africa and secondly to propose a model for facilitating the acquisition of $L 2$ literacy. In the first part of this paper, $\mid$ briefly discuss pedagogical approaches to literacy and consider how the findings of recent research into the nature of the relationship between orality and literacy yield insight into literate language behaviour. In the second part of the paper, I propose an approach to the teaching of academic literacy in the $L 2$ that arises from these insights (Tannen 1982, 1985).

One of the major problems in education in South Africa at present concerns the language of instruction. Although our constitution recognizes the multilingual reality of our nation, the reality is that the majority of South Africa's learners are receiving instruction in a language other than their mother tongue, namely English. For the purposes of this paper, I shall use the term L2 literacy to refer to literacy in English, even though English may be a third or a foreign language to many South African learners.

Educational practices and language policies in South Africa are such that learners commence their primary schooling in the first language and then switch to instruction in English in the $3^{\text {rd }}$ grade. This may have serious pedagogical implications as findings in linguistic research indicate that learners acquire $L 2$ literacy more successfully if they have already acquired L1 literacy (Street 1994:23, Verhoeven 1994:216). For South African learners, this early transition to $L 2$ instruction means that they do not have the opportunity to master literacy in the $L 1$. However, the problem is even more complex as, apart from having to acquire functional, sociocultural and expressive literacy in the $L 2$, they need to acquire academic literacy in the $L 2$ in order to advance academically. 
At the end of 1998, the Department of Education made a gesture to compensate nonEnglish speaking Secondary School Certificate candidates for the impediments imposed by second-language instruction by adding $1,05 \%$ to the marks they obtained in each subject (Pretoria News 1998). However, this is merely a compensatory measure which does nothing to address the problem. In fact, it is a clear indication to linguists and educational policy-makers that there is an urgent need to focus on strategies for assisting learners to acquire academic literacy in the $L 2$.

The model I propose for facilitating the acquisition of L2 literacy has its theoretical underpinnings in the findings of recent research on the relationship between orality and literacy known as the 'New Literacy Studies' (Carter 1995, Gee 1990, Street 1994, 1995) and a genre-based approach to $L 2$ teaching which cuts across the spoken and written modes and focuses on the communicative purpose of the discourse (Tannen $1982,1985,1989$ ).

\section{THE 'NEW LITERACY STUDIES'}

Over the last decade, the research carried out on literacy in a variety of disciplines such as linguistics, social psychology, cultural anthropology and education has resulted in a body of literature termed the 'New Literacy Studies' (Carter 1995:98, Street 1994:13). What is 'new' about the 'New Literacy Studies' is that it emphasizes the sociocultural, ideological context of literacy and rejects the assumed 'orality-literacy dichotomy' that characterized approaches to literacy from the 1960 s to the 1980 s.

The traditional concept of an 'orality-literacy dichotomy' is based on the false assumption that communication in the written channel is autonomous or contextindependent and that the acquisition of literacy has social and cogritive consequences for the individuals in the society in which it develops (Goody 1986, Goody and Watt 1963). The assumed orality-literacy dichotomy is represented below: 


\section{ASSUMED ORALITY-LITERACY DICHOTOMY}

(Chafe 1985)

\begin{tabular}{|l|l|}
\hline \multicolumn{1}{|c|}{ ORAL DISCOURSE } & \multicolumn{1}{c|}{ WRITTEN DISCOURSE } \\
\hline Spontaneous, unplanned, informal & Planned, formal \\
\hline Contextualized & Decontextualized, autonomous \\
\hline Characterized by interpersonal involvement & Characterized by detachment \\
\hline $\begin{array}{l}\text { Characterized by syntactic fragmentation } \\
\text { and syntactic simplicity }\end{array}$ & $\begin{array}{l}\text { Characterized by syntactic integration and } \\
\text { syntactic complexity }\end{array}$ \\
\hline $\begin{array}{l}\text { Cohesion achieved through paralinguistic } \\
\text { cues }\end{array}$ & $\begin{array}{l}\text { Cohesion achieved through lexicalization } \\
\text { and syntax }\end{array}$ \\
\hline $\begin{array}{l}\text { Conerence achieved by reliance on shared } \\
\text { knowledge }\end{array}$ & $\begin{array}{l}\text { Coherence achieved by explicit statements } \\
\text { and linking of ideas }\end{array}$ \\
\hline
\end{tabular}

In terms of the assumed orality-dichotomy, cultural anthropologists (Goody and Watt 1963) claimed that the cognitive processes of literate individuals were more abstract, logical and complex than those of pre-literate individuals and that therefore, the acquisition of literacy would result in improved social and economic circumstances of the society in which it developed. These claims, known as the 'literacy hypothesis' have been challenged by present-day anthropologists (Street 1994) and linguists (Tannen 1985 , Nystrand 1987, Heath 1982, Halliday 1987) and are no longer regarded as true. in terms of the 'New Literacy Studies', literacy is not an autonomous technology for which consequences can be claimed, but merely one of many interacting social and cultural practices. There is thus no single definition or unified concept of literacy; instead, literacy is regarded as a multiplicity of competencies deeply rooted in the ideology of a society.

\subsection{The ideological context of iteracy}

The ideological context of literacy is most prominent in the 'pedagogization' of literacy, namely, the way in which the dominant classes in a society can determine who has access to literacy, to what extent they have access to literacy and through which 
language they are allowed to practise literacy (Street 1995:107). The paradox is thus that, whereas literacy can be liberating, it can also be enslaving, depending on the ideological forces that shape the way in which it is practised in a particular society. In South Africa, prior to 1992, literacy practices and educational policies were strictly ideologically controlled with the result that, for most learners, English is now regarded as the language of access to education and to advancement in other spheres of life such as politics and economics.

Findings in linguistic research indicate that $L 1$ instruction is the optimum learning channel (Verhoeven 1994:216). In teaching L2 literacy, it is generally assumed that learners are already literate in the $\mathrm{L} 1$, or that they have some experience in forms of literate language behaviour in the mother tongue. However, in South Africa, where, for ideological reasons, the $L 2$ has been chosen as the language of instruction, it is doubtful whether such competence is achieved in the L 1 before learners switch to the $L 2$ as the medium of instruction. In the L2 teaching they receive, the emphasis is on achieving communicative competence rather than on using the target language for specific or academic purposes. It is thus a fact that most South African learners do not have the opportunity to acquire academic fiteracy in the L1 before they start receiving instruction in the $\mathbf{L} 2$.

In terms of the 'New Literacy Studies', academic discourse is not neutral and autonomous, but highly conventionalized and ideologically contextualized. Therefore, to be academically literate means to be able to speak, read, write and behave in the way expected or favoured in the type of formal education conventionalized in a specific society. In South Africa, this involves achieving academic literacy in the $L 2$, namely in English, and learning to control the genres favoured by the acadernic institutions of the western world. To achieve academic success, learners need to control the genres relevant to the disciplines that constitute the curricuium; they need to be able to comprehend and produce the spoken expository genres (such as spoken lectures) as well as the written expository genres favoured by the academic community of which they are part. It is thus essential for South African leamers to be given explicit instruction in 
the academic genres favoured by the institutionalized processes of learning and teaching (Street 1994:24). It is also essential for teachers to be given the necessary support to deal with the language needs of the curriculum as well as the genres conventionalized in the pedagogic context.

\subsection{How is L2 literacy acquired?}

In what way is the process of acquiring $L 2$ literacy different from that of acquiring $L 1$ literacy? In the continuing debate about appropriate strategies for L2 literacy acquisition, various approaches have been proposed

Verhoeven (1994:216) claims that one way of looking at L2 literacy learning is to refer to the strategies employed in the acquisition of L1 literacy. He (1994:209) supports a transitional approach in which learners first acquire L1 literacy before proceeding to learn $\mathcal{L} 2$ literacy, his assumption being that the acquisition of $L 2$ literacy is made more easy if it is based on familiar exemplars from the mother tongue.

However, Bhatia (1997:136) claims that an almost perfect competence in the L2 code is not necessarily a prerequisite for achieving proficiency in L2 academic literacy. According to him, the claim that learners will be able to cope with $L 2$ literacy for academic purposes when they have acquired a communicative competence in the $L 2$ is a flawed hypothesis based on the naïve assumption that the difference between everyday discourse and specialist discourse rests on the use of a specialist lexis or terminology. Bhatia's (1997:136) research on genre analysis strongly indicates that there are fundamental differences in the use, not only of the lexical-grammatical, but also the semantic-pragmatic and the discoursal resources of specific genres. He therefore maintains that learners need to be taught the strategies or rhetorical procedures of the genres required for academic purposes in the $L 2$ whether they have or have not acquired communicative competence in this channel.

Hammond and Freebody $(1994: 234)$ find that, although learners achieve a measure of 
control over the informal, oral genres of the $L 2$, they experience difficulties in producing the written genres that constitute part of academic discourse. They maintain that an effective way of dealing with this problem is to focus learners' attention on the similarities between spoken and written academic discourse of the same genre. Learners should know how the two modes relate and that it is the nature of the genre rather than the mode that determines the features of the discourse. For instance, certain written genres, such as narratives, can exhibit features associated with spoken discourse; certain spoken genres, such as academic lectures, can exhibit features associated with written discourse.

Kaplan (1997:18) finds that most leamers are not aware that the organization of written text is culture-specific. They do not know how 'text-logic' is organized in their L1 or in their $L 2$, or even that there is a difference. They therefore need to be given explicit instruction in the genres they need to manipulate in academic discourse in the L2. Similarly, Ferreiro (1994:234) believes that L2 literacy instruction should focus on the functional motivation for language and should emphasize genre as embodying the correlation between form and function.

Although there is no absolute consensus among linguists on the way in which $L 2$ literacy is best acquired, they agree on the important role of oral proficiency in the acquisition of L2 literacy and on the important role of genre awareness in the acquisition of L2 academic literacy. Teachers should therefore tap into their learners' $L 1$ and $L 2$ oral proficiency to heighten learners' awareness of how discourse is organized.

\subsection{Genre awareness}

What are the outcomes or the competencies we require learners to demonstrate as evidence that they have achieved literacy in the L2? We not only expect them to demonstrate a knowledge of the orthographic code or of the syntax of the target language, but also an understanding of how the internal structure of the text relates to its communicative function or genre. This involves being able to point out, as well as 
manipulate, the logical relations constituting the exposition of the content. This also involves demonstrating an understanding of the pragmatic code of a text, such as its communicative purpose, to whom it is addressed and within what context it is situated. Leamers therefore need to develop control not only of content but also of the forms or favoured genres of discourse.

in a genre-based approach, form and content are inextricably linked. A genre-based approach is therefore likely to focus learners' attention on the rhetorical 'moves' and on the organizational means whereby the text accomplishes its communicative purpose (Swales 1990:138).

An important feature of genre analysis is that it does not distinguish between spoken and written discourse, but cuts across mode and focuses on the strategies required for effective communication in specific genres. This is another indication that the relationship between spoken and written discourse is more complex than previously thought. In devising approaches to writing, we should therefore place more emphasis on the relationship between spoken and written discourse instead of stressing the differences between the two modes.

\section{MODE-MIXING}

In adopting a mixed-mode approach to the teaching of academic writing, I have been guided by insights derived from the findings of Tannen's (1982:37) investigation of spoken and written discourse of similar genres. Her findings indicate that features, traditionally associated exclusively with either spoken or written discourse, interact in discourse of either mode. Both spoken and written discourse rely on the same strategies for effective communication, namely involvement strategies traditionally thought to be exclusive to spoken discourse. In these terms, mode-mixing is a feature of all discourse whether it is realised in the spoken or the written mode. Consequently, Tannen (1982:37) claims that the previously assumed orality-literacy dichotomy is a 'myth'. It is important to note that she does not equate speech with writing but focuses 
on the interactive relationship that holds between them. Her rebuttal of the oralityliteracy dichotomy ties in with the insights derived from the 'New Literacy Studies', namely that 'literacy practices are always embedded in oral uses' and that the 'variations between cultures are generally variations in the mix of oral/literate channels' (Street 1988:5).

An understanding of the relationship between spoken and written discourse is therefore central to the teaching of literacy and to facilitating the acquisition of $L 2$ literacy. However, this relationship is still not well understood as most language teaching still reflects the traditional orality-literacy divide in that writing, especially the writing of expository essays, is treated as a separate, higher order skill and the use of spokenmode features in written expository essays is often negatively evaluated.

Tannen (1982:37) maintains that two main myths or fallacies about written discourse which originate in the assumed orality-literacy dichotomy are still being upheld. These are, firstly, that written discourse is decontextualized or autonomous, and secondly, that written discourse is syntactically more complex than spoken discourse. Consequently, there is still a tendency among teachers to overstate the 'autonomy' of written discourse and to insist that learners use syntactic structures such as agentless passive verbs and nominalizations in their writing.

In terms of the 'New Literacy Studies', it is a fallacy to assume that written discourse is autonomous. All discourse is contextualized to a certain extent; even written expository academic discourse relies on being contextualized within the reader's world of experience in order to be effective (Tannen 1989:9-12). Whereas spoken discourse is produced and received within one and the same context in which both speaker and listener are present, written discourse actually has two contexts: a 'context of expression' within which it is composed, and a 'context of eventual use' within which it is received (Nystrand 1987:205). Written discourse, like spoken discourse, is thus a communicative act between participants and is also produced for a context - one of 'eventual use'. 
It is also a fallacy to assume that written discourse is syntactically more complex than spoken language. There are instances of spoken language which, upon analysis, prove to be syntactically just as complex as the written version (Halliday 1987:68). A syntactic analysis of the following spoken and written versions of the same sentence illustrates the way in which both modes exhibit syntactic complexity, albeit of a different type (Halliday 1987:65):

(a) (Spoken version)

Whenever l'd visited there before, l'd end up feeling that other people might get hurt if I tried to do anything more.

(b) (Written version)

Every previous visit had left me with a sense of the risk to others in further attempts at action on my part.

The spoken version (a) is a complex sentence containing four clauses, namely Whenever l'd visited there before, /l'd end up feeling / that other people might get hurt if I tried to do anything more. The written version (b) is a simple sentence consisting of a single clause. Therefore, the spoken version exhibits greater hypotactic complexity than the written version. However, the written version exhibits a different kind of syntactic complexity, namely the device involving nominalization whereby the propositions are reduced to nouns or noun phrases, such as Every previous visit / a sense of the risk / in further attempts / at action on my part. A syntactic analysis of these spoken and written versions of the same sentence therefore indicates that both modes are syntactically complex, but that the type of complexity tends to vary. The syntax of the spoken version is characterized by hypotactic complexity, active verts and agency, e.g. Whenever $\underline{l} d$ (agent) visited (active verb) ..., whereas the written version is characterized by nominalizations and by agentless passive verbs, e.g. Every previous visit (nominalization) had left me (passive vert and suppression of agency) ....

The syntactic devices that characterize the written version, such as the agentless passives and nominalizations, achieve the effect of detachment as the agency and the 
involvement of the writer are suppressed. L2 learners may experience difficulty with such syntactic devices involving passive verbs, nominalizations and the suppression of agency because they are less familiar to them than are the active verbs and the expression of agency which characterize their spoken discourse. However, many teachers still tend to evaluate the written expository discourse of their learners in terms of how they succeed in achieving the detachment and the syntactic complexity believed to be a property of written discourse.

The question that arises is why such syntactic conventions are more highly evaluated in written discourse. Why should learners be encouraged to efface their own 'voices' and to write 'authorless' texts by using the third person pronoun, agentless passive structures and nominalizations, e.g. In this essay, the aim is to argue that the tragic consequences are ...? Learners find it difficult to manipulate the unfamiliar syntactic devices involving passive verbs and nominalizations in order to achieve the detachment conventionally associated with written expository discourse. They also find it difficult to express a rhetorical stance towards the topic while simultaneously having to manipulate syntactic structures that suppress their own 'voice' and agency.

Present day linguists (Heath1982:114, Tannen 1985:128) argue that detachment and depersonalization are not inherent properties of written discourse. The notion that written expository discourse is autonomous, decontextualized and impersonal is based on false assumptions about the features characterizing written discourse. Learners need to acquire control over the requisite written genres through which they can demonstrate their academic competence; therefore they should not be confused by being taught to suppress their own involvement and agency. Teachers who encourage L2 learners to strive towards achieving detachment and depersonalization in their writing, are actually impeding rather than facilitating the acquisition of literacy. Instead, teachers should be assisting $L 2$ learners to communicate effectively in their written discourse through using a 'mixed-mode' style of writing, in which they exploit familiar strategies associated with spoken discourse. The teaching of literacy would be more effectively supported if teachers were better informed about the interactive relationship 
between the two modes.

Tannen (1982:37) states that the main reason for the false claims made about the differences between spoken and written discourse respectively, is that scholars have not taken into account the effects of genre. According to her $(1985: 127)$ theory, the nature of the genre, or the communicative purpose of the discourse, has more effect on the form of the discourse than the mode in which the discourse is realized. She claims that the key dimension distinguishing various genres of discourse is the relative focus achieved on interpersonal involvement as opposed to content. The variation in the degree of focus on involvement rather than on content depends more on the communicative purpose or the genre of the discourse than on whether the discourse is realized in the spoken or the written mode.

\subsection{Relative focus on involvement in spoken and written discourse genres}

The point of departure in devising a 'mixed-mode' approach to writing is Tannen's $(1985: 129)$ claim that relative focus on involvement is the main factor determining the features of a discourse, whether spoken or written.

In terms of Tannen's (1985:127) theory of relative focus on involvement, all discourse, even expository written academic discourse, relies on a certain degree of interpersonal involvement to engage the attention and the interest of the readers/listeners, otherwise they will not be motivated to focus on the content. It is a fallacy to think that written discourse genres, such as expository academic essays, do not rely on involvement strategies previously associated with spoken discourse (Tannen 1885;129). Such involvement strategies are contextualization, shared knowledge between the participants in the discourse, and rhetorical features such as the stance of the speaker/writer towards the subject of the discourse and towards other participants such as the readers/isteners. Tannen's theory of relative focus on involvement is represented below: 
RELATIVE FOCUS ON INVOLVEMENT IN DISCOURSE (Tannen 1985)

The key dimension distinguishing discourse is the relative focus on involvement as opposed
to content or message.
$\begin{aligned} & \text { The relative focus on involvement results from the effects of genre rather than from } \\ & \text { differences in mode. }\end{aligned}$
$\begin{aligned} & \text { Spoken discourse (spontaneous conversation) is the source of strategies whereby } \\ & \text { interpersonal involvement is achieved in written discourse, including expository genres. }\end{aligned}$

Tannen's (1985:127) theory is that the main feature distinguishing discourse is the extent to which it focuses on interpersonal involvement as opposed to content or message. She (1982:37) maintains that spoken discourse, such as spontaneous conversation, is the source of involvement strategies upon which all discourse, even written expository discourse, relies to achieve involvement. Spontaneous conversation focuses relatively more on interpersonal involvement than on content, whereas expository discourse, whether spoken or written, focuses relatively more on content than on interpersonal involvement. However, without a certain degree of interpersonal involvement, expository written or spoken discourse will not succeed in fulfilling its communicative purpose.

\subsection{The writer as speaker - the reader as listener}

We need to question the methods according to which we are teaching expository discourse. Do we perhaps place too much emphasis on the differences between spoken and written discourse, instead of stressing the similarities between expository genres in the two modes? Should we not be focusing on the features common to the genre, rather than on the so-called differences in mode? Should we not be investigating the nature of the genres of oral discourse in the learners' $L 1$ and $L 2$ and showing them how certain features characterize specific genres whether spoken or written?

Foregrounding the features traditionally associated with spoken discourse is of particular relevance in the teaching of $L 2$ writing. In such an approach, learners focus on the 
'spoken' characteristics of written discourse and are encouraged to 'mix' the features traditionally associated with each mode. They learn that, depending on the genre, spoken discourse can be written-like and written discourse can be spoken-like (Tannen 1985:127). Expository writing, while focusing on conveying content or information, still relies on strategies traditionally associated with spoken discourse in order to achieve the interpersonal involvement necessary for engaging the interest of the reader. These features, traditionally associated with spoken discourse, are listed in the following table:

\section{ACHIEVING INVOLVEMENT IN WRITTEN DISCOURSE THROUGH 'MODE-MIXING'}

\begin{tabular}{|l|l|}
\hline $\begin{array}{c}\text { Features traditionally associated with } \\
\text { spoken discourse }\end{array}$ & \multicolumn{1}{|c|}{ Involvement } \\
\hline Use of first and second person pronouns & $\begin{array}{l}\text { illusion of spatiotemporal proximity - } \\
\text { interpersonal involvement between } \\
\text { participants in the discourse }\end{array}$ \\
\hline Contextualization & $\begin{array}{l}\text { Assumption of shared background between } \\
\text { writer/speaker and reader/listener }\end{array}$ \\
\hline Reciprocity, rapport, participation & $\begin{array}{l}\text { Dialogic mode foregrounded - discourse } \\
\text { achieves the tone of a monologue } \\
\text { addressed to an implied listener }\end{array}$ \\
\hline Relatively informal register & $\begin{array}{l}\text { Strategies (conventionally thought to be } \\
\text { exclusive to spoken discourse), e.g. } \\
\text { repetition, rhetorical questions }\end{array}$ \\
\hline Indication of rhetorical stance & $\begin{array}{l}\text { Attitude and evaluation signalled through } \\
\text { lexicalization and explicit statement }\end{array}$ \\
\hline Syntax characterized by the use of the & $\begin{array}{l}\text { Agency, relative absence of nominalization, } \\
\text { relative absence of passive voice }\end{array}$ \\
\hline active voice
\end{tabular}

In the academic environment, the genre most highly valued is that of the expository essay or lecture. A written academic essay and a spoken academic lecture both represent the same genre of expository discourse even though they are each realized in a different mode. Most leamers find it difficult to write essays because many teachers still expect written expository discourse to be characterized by detachment, depersonalization and syntactic structures involving passive verbs and nominalizations. 
Consequently, $L 2$ learners tend to regard the essay as a complex form of language behaviour, far removed from the interactive, interpersonal involvement they associate with spoken discourse (Carter 1995:99).

However, an essay generally represents a genre in which writers have to 'state a case' or argue in order to 'prove a point'. Constructing an argument is an activity close to speech and is at its best when the writer's personal 'voice' is 'heard' (McCarthy and Carter 1994:48). Learners shouid be encouraged to use the first and second person pronouns to achieve a personal rather than an impersonal tone. This could obviate the problems they experience when dealing with the syntax of agentless passives, such as $I t$ is assumed that ... and nominalizations, such as The assumption that ....

Teachers should assist leamers to contextualize their essays by giving careful attention to expressing the rubrics or instructions in such a way that learners are able to imagine or visualize a 'context of eventual use' (Nystrand 1987:205). The findings of research with regard to rubrics indicates that $L 2$ leamers perform better when given a rubric with a high rhetorical specification such as a short introductory statement followed by an instruction to respond (Hamp-Lyons 1991:91). The instruction should contain a certain amount of stimulus or 'input material' as well as some indication of the 'audience' of the discourse. The instruction should also give learners a scenario for which they can posit a context, for example:

Romeo and Juliet are often described as 'two star-crossed lovers' doomed to tragedy, or as victims of fatal flaws in their characters. However, should they not rather be seen as two young people whose desperate conflict with the authoritarian structures of their society results in tragedy?

Write an essay of about three pages in which you argue for or against this interpretation of the play Romeo and Juliet. Indicate your stance towards the topic in the first paragraph of your essay, e.g. 'I support the interpretation ... '. Your argument should involve a discussion of the authontarian structures to which Romeo and Juliet are opposed, how they come into conflict with them and the people who enforce them, and why you think their conflict has tragic consequences. Bear in mind the fact that 1 , your reader/listener, have read the play and am interested in hearing your argument; therefore avoid giving me a narration of the plot but focus your discussion on the issues stated in the rubric. 
Although this rubric may be regarded as prescriptive or as an instance of 'spoonfeeding', it encourages learners to adopt a rhetorical stance and to argue according to their own ideas rather than repeating vast passages from secondary texts on the drama or relying on rote learning.

The above rubric prompts the writer/speaker to create an imaginary context for the discourse, namely to explain to a reader/listener how the two characters in the drama are engaged in a discourse with their society. The rubric also stresses the participatory nature of the discourse by stating clearly who the reader/listener is. The speaker/writer is able to form an idea of the 'context of eventual use' (Nystrand 1987:205) and of the rapport that he or she should strive to achieve with the reader/listener. The rubric evokes the idea of spatio-temporal proximity between the participants so that the writer/speaker can simulate 'face-to-face communication' with the reader/listener and achieve interpersonal involvement. The rubric also encourages interaction between writer/speaker and reader/listener through the rhetorical questions, e.g. ... should they not rather be seen as two young people whose desperate conflict ...? The use of the first and second person pronouns might indicate to the writer/speaker that the register of the discourse could be relatively informal.

The rubric states that there is a certain amount of shared knowledge between the participants; this may have the effect of simplifying the writer/speaker's problem of what to include and what to exclude in the essay. The writer/speaker may find it easier to focus on the issues for discussion and not lapse so easily into a re-telling of the plot. The rubric also invites the writer/speaker to 'indicate' his or her 'stance' with regard to the topic and to take the responsibility for his or her opinions. The writer/speaker is encouraged to express his or her opinions directly, in the first person, e.g. I support the interpretation that ... instead of using agentless passives and nominalizations such as, In this essay, it is arqued that the conseguences of .... The rubric does not require learners to write 'authorless' essays without ever using the first person pronoun, or the active voice. Instead, it encourages them to take responsibility for their own opinions 
and to express their own agency in this regard.

Through simulating the situation of 'face-to-face' discourse, learners may find it easier to achieve the immediacy associated with spoken discourse and to anchor the discourse deictically in the present tense conventionalized for academic writing, e.g. 'Shakespeare says ...' .

Teachers with insight into the relationship between spoken and written discourse would not evaluate features associated with spoken discourse negatively. They would realize that $\mathrm{L} 2$ learners are drawing on their oral proficiency and are using familiar syntactic structures such as sentences characterized by a series of clauses with active verbs involving first and second person pronouns as subjects and agents. They would also realize that such syntactic structures are relatively complex and that through manipulating them successfully, learners are demonstrating a level of proficiency in L2 literacy (Halliday 1987:68). Obviously, the reader/listener will only succeed in encouraging the writer/speaker to sustain the transactional nature of the discourse if he or she behaves as a non-intimidating, co-operative participant. The teacher should therefore not represent an authoritarian, censorious critic, but be perceived as a participant in the discourse with whom the writer/speaker can 'speak' and argue. The emphasis in assessing the essay should be on rhetorical competence rather than on grammatical and orthographic correctness.

Spoken discourse and written discourse have more in common than previously realized. Spoken discourse, such as spontaneous conversation, is not as disorganized as generally thought, but proceeds in an orderly fashion, in a series of rhetorical 'moves' (Swales 1990:141). The moves and turns proceed according to the way in which the participants establish the extent of their shared knowledge (Tannen 1989:6). Conversational discourse, like written discourse, has openings and closings. The opening or introduction signals what is to take place, establishes the theme or topic and indicates the organization of the discourse. Here again, genre awareness is relevant. When assisting learners to structure their expository writing, teachers should be able to stress that, in an expository genre, the topic for discussion generally needs to be 
stated explicitly, whereas in the genre of spontaneous conversation, it is generally shared and implicit.

To facilitate their awareness of the requirements of the expository genre, learners could initially be given a 'checklist' of prompts which they could bear in mind as they write, or which they could enter in a margin alongside their essay. This should not be seen as restrictive. Expository genres do not have an invariant organization; there is a range of linguistic patterns and structures which L2 learners may select. Initially, however, L2 learners need prompts to assist them with the structuring of the content of their discourse and to help them overcome their fear of the blank page. In learning 12 literacy, learners need to discover how they can 'speak with a voice that will be heard in the new culture' (Hamp-Lyons 1991:59). Such prompts also help learners to clarify what assessment criteria are involved in judging the writing task. The use of such prompts is illustrated below, together with fragments of writing from an expository essay written by a final year teacher-trainee diploma student at the Vista University Distance Education Campus:

\section{1" MOVE (INTRODUCTION)}

\begin{tabular}{|c|c|}
\hline Prompts & Fragments of writing \\
\hline $\begin{array}{l}\text { Tell me what you are going to do in this } \\
\text { essay. } \\
\text { Does your introductory paragraph contain a } \\
\text { thesis statement, clearly indicating to me and } \\
\text { other readers/listeners what you are going to } \\
\text { do or say in the essay? } \\
\text { Does it also contain a statement of your point } \\
\text { of view or attitude towards the topic, i.e. } \\
\text { whether you agree or disagree with it? } \\
\text { Do you give me and your readers/listeners a } \\
\text { brief preview of what we are going to 'hear' } \\
\text { from you? }\end{array}$ & $\begin{array}{l}\text { I support the interpretation that Romeo and } \\
\text { Juliet are two young people in conflict with } \\
\text { the authoritarian structures of their society. } \\
\text { in this essay l intend to discuss authoritarian } \\
\text { structures such as the code of honour that } \\
\text { prevailed in Verona and the strict parental } \\
\text { authority that dominated their lives. I also } \\
\text { intend to argue that their conflict with these } \\
\text { structures leads to tragedy. }\end{array}$ \\
\hline
\end{tabular}


From the above fragments of writing, it can be seen that the writer/speaker is responding to the prompts by using a 'speaking voice'; she is 'speaking' to a hypothetical 'listener' rather than writing for an unknown reader. Through the use of the first person pronoun, her essay achieves the effect of a spoken address to an audience, or a monologue directed at a definite listener. Her writing is a dynamic, communicative 'act', a process of interaction between a 'speaker' and a 'hearer' (Harvey 1997:119).

The writer/speaker is writing for a 'context of eventual use' (Nystrand 1987:205). By bearing her reader/listener in mind, she is expressing her point of view through adopting a rhetorical stance with regard to the argument. She aims at persuading the implied reader/istener to adopt her point of view in the introduction by statements such as I support ... , l intend to discuss ... , l intend to argue ... .

The moves that constitute the internal environment of the text are the ones that could prove to be problematic (Carter 1995:23). Here again, genre awareness is important as $L 2$ learners need to be made aware of the major difference between the expository essay-type genre and the genre of conversation. The essay genre is topic-focussed whereas spontaneous conversation is topic-associated. The challenge that faces learners is how to develop an argument while achieving a logical progression and organization of ideas as well as maintaining their focus on the topic. Learners could also be made aware of how the rhetorical structure of a written expository essay is the same as that of a spoken academic lecture. The development of the argument in a written essay could proceed as a series of 'moves' as it would in a spoken lecture: 
THE ARGUMENT: A SERIES OF MOVES

\begin{tabular}{|c|c|}
\hline Prompts & Fragments of writing \\
\hline $\begin{array}{l}\text { Do you develop your argument in a few } \\
\text { paragraphs? } \\
\text { Do you discuss each idea/supporting } \\
\text { argument from your introduction in a } \\
\text { separate paragraph? } \\
\text { Does each idea focus on the topic stated in } \\
\text { the rubric and in the introduction? } \\
\text { If you maintain your topic-focus, your ideas } \\
\text { should follow one another logically and be } \\
\text { linked by words such as the following; firstly; } \\
\text { secondly; consequently; therefore .... } \\
\text { Can you relate what you are saying in each } \\
\text { paragraph to the topic of your essay? } \\
\text { Can you indicate, by means of arrows, that } \\
\text { your paragraphs each 'link up' with the topic? }\end{array}$ & $\begin{array}{l}\text { The first authoritarian structure Romeo and } \\
\text { Juliet come into conflict with is the Veronese } \\
\text { code of honour which involves.... The code } \\
\text { of honour affects them in the following ways: } \\
\text { Firstly, there is a feud between their families } \\
\text {... Secondly, Romeo is drawn into the feud } \\
\text { when he has to defend the honour of } \\
\text { Mercutio.... Although.... } \\
\text { The second authoritarian structure the } \\
\text { couple come into conflict with is parental } \\
\text { authority. Juliet's father behaves in an } \\
\text { authoritarian way when he arranges a } \\
\text { marriage between her and County Paris .... } \\
\text { As a result of these authoritarian structures } \\
\text {... }\end{array}$ \\
\hline
\end{tabular}

In developing the above argument, the writer/speaker 'speaks' with authority and is personally accountable for her opinions. The tone of 'voice' that emerges through the use of the first person pronoun, the active structures and the expression of Agency, is one of confidence. She assumes a certain amount of shared knowledge between herself and her readerfistener with regard to the plot of the drama; hence she focuses only on the issues required of the topic and does not narrate the details of the plot. Her argument develops according to supporting statements which, assisted by the prompts, she can link to her thesis statement in her first paragraph. She is able to round off her argument in the concluding paragraph with a statement commencing with Therefore ... which she links to the rubric: 
FINAL MOVE: CONCLUSION

\begin{tabular}{|c|c|}
\hline Prompt & Fragments of writing \\
\hline $\begin{array}{l}\text { Now tell me what you did in this essay. } \\
\text { Have you accomplished your communicative } \\
\text { purpose? } \\
\text { If so, you should be able to state: Therefore } \\
\text {... and refer to your stance towards the topic } \\
\text { or issue stated in the rubric and the } \\
\text { introductory move. }\end{array}$ & $\begin{array}{l}\text { Therefore, I agree with the interpretation that } \\
\text { Romeo and Juliet are tragically destroyed } \\
\text { while trying to oppose the authoritarian } \\
\text { structures of the society in which they live. }\end{array}$ \\
\hline
\end{tabular}

\section{CONCLUSION}

The main advantage of a mixed-mode approach is that $L 2$ leamers gain insight into the way in which, as writers/speakers, they can exploit strategies in both spoken and written discourse to achieve the involvement of their readers/listeners. In such an integrated approach, L2 learners can draw on their oral proficiency to fulfil the communicative purpose of their writing and so develop the confidence to meet the demands of academic literacy in the L2.

\section{*ACKNOWLEDGEMENT}

This article is a revised version of part of a thesis submitted to the Department of General Linguistics at the University of Stellenbosch in 1997 in partial fulfilment of the requirements for the DPhil degree in General Linguistics. I wish to acknowledge the contribution of the Department and, in particular, that of Prof. RP Botha in supervising the work from which this article resulted. 


\section{REFERENCES}

Bhatia, V. K. 1997. Applied genre analysis and ESP. In Miller, T. (ed.) Functional approaches to written text: classroom applications. Washington: English Language Programs, United States Information Agency. 134-149.

Carter, R. 1995. Keywords in language and literacy. London: Routledge

Chafe, W. L. 1985. Linguistic differences produced by differences between speaking and writing. In Olson, D. R., Torrance, N. \& Hildyard, A. (eds.) Literacy, language and leaming: the nature and consequences of reading and writing. Cambridge: Cambridge University Press. 105-123.

Ferreiro, E. 1994. Problems and pseudo-problems in literacy development: focus on Latin America. In Verhoeven, L. (ed.) Functional literacy: theoretical issues and educational implications. Amsterdam/Philadelphia: John Benjamins. 223-235.

Gee, J. P. 1990. Social linguistics and literacies: ideologies in discourses. Basingstoke: The Falmer Press.

Goody, J. 1986. The logic of writing and the organization of society. Cambridge: Cambridge University Press.

Goody, J. \& Watt, I. P. 1963: The consequences of literacy. Comparative studies in society and history 5. 304-345.

Halliday, M. A. K. 1987. Spoken and written modes of meaning. In Horowitz, R. \& Samuels, S. J. (eds.) Comprehending oral and written language. San Diego: Academic Press 55-82.

Hammond, J. \& Freebody, P. 1994. The question of functionality in literacy: a systemic approach. In Verhoeven, L. (ed.) Functional literacy: theoretical issues and educational implications. Amsterdam/Philadelphia: John Benjamins. 425-443.

Hamp-Lyons, L. 1991. The writer's knowledge and our knowledge of the writer. in Hamp-Lyons, L. (ed.) Assessing second language writing in academic contexts. Norwood, New Jersey: Ablex Publishing Co. 51-68.

Hamp-Lyons, L. 1991. Pre-text: task-related influences on the writer. In Hamp-Lyons, L. (ed.) Assessing second language writing in academic contexts. Norwood, New Jersey: Ablex Publishing Co. 87-107.

Harvey, A. M. 1997. The voices of the discourse or the problem of who says what in news reports. In Miller, T. (ed.) Functional approaches to written text: classroom applications. Washington: English Language Programs, United States Information Agency. $119-133$ 
Heath, S. B. 1982. Protean shapes in literacy events: ever-shifting oral and literate traditions. In Tannen, D. (ed.) Spoken and written language: exploring orality and literacy. Norwood, N. J.: Ablex Publishing Co. 91-117.

Kaplan, R. B. 1997. Contrastive rhetoric. In Miller, T. (ed.) Functional approaches to written text: classroom applications. Washington: English Language Programs, United States Information Agency. 18-32.

McCarthy, M. \& Carter, R. 1994. Language as discourse: perspectives for language teaching. Longman: London \& New York.

Nystrand, M. 1987. The role of context in written communication. In Horowitz, R. \& Samuels, S. J. (eds.) Comprehending oral and written language. San Diego: Academic Press. 197-214.

Pretoria News. 1998. Gauteng pass rate is up by $4,1 \%$. December 31 .

Street, B. 1994. The implications of the New Literacy Studies for the new South Africa. Joumal of Literary Studies 10(1). 13-30.

Street, B. 1995. Social hiteracies: critical approaches to fiteracy in development, ethnography and education. London and New York: Longman.

Swales, J. M. 1990. Genre analysis: English in academic and research settings. Cambridge: Cambridge University Press.

Tannen, D. 1982. The myth of orality and literacy. In Frawley, W. (ed.) Linguistics and literacy. New York: Plenum Press. 37-50.

Tannen, D. 1985. Relative focus on involvement in oral and literate discourse. In Olson, D. R., Torrance, N. \& Hildyard, A. (eds.) Literacy, language and leaming: the nature and consequences of reading and writing. Cambridge: Cambridge University Press. 124-147.

Tannen, D. 1989. Talking voices: repetition, dialogue and imagery in conversational discourse. Cambridge: Cambridge University Press.

Verhoeven, L. 1994. Linguistic diversity and literacy development. In Verhoeven, L. (ed.) Functional literacy: theoretical issues and educational implications. Amsterdam/ Philadelphia: John Benjamins. 199-220. 